\title{
Training Orang Utans for the Wild
}

\section{G. S. de Silva}

Since 1964 the author, who is Game Warden of Sabah (formerly British North Borneo) has been running a state-supported orang utan rehabilitation project in the Sepilok Forest Reserve. Most are confiscated animals, having been kept illegally, often as pets, and he describes some of the difficulties in getting them to become independent again and able to live in the forest. Some have even been too well treated in captivity, living luxuriously and treated like humans.

Sabah is still rich in wild life-especially in primates-and remains one of the strongholds of the rare and seriously endangered orang utan, Pongo pygmaeus pygmaeus, which is distributed throughout the country. The greater part of the state is covered with dense, evergreen, tropical rain forest but the accelerated rate at which land is being opened up is a serious threat to the wildlife. Not only is the habitat reduced, but during jungle clearing operations female apes are shot or otherwise killed and their young captured despite stringent protection laws. The recent killings suggest that the orang is also being hunted in connection with pagan ritual and the concoction of dubious medicines. In Sabah, where hunting is a way of life among the indigenous people, it is extremely difficult to stress the importance of conservation on cultural, scientific or aesthetic grounds, and to them the game laws are a constant source of irritation. However, all illegal killings or captures are investigated, the offenders prosecuted where possible, and the animals confiscated and handed over for disposal to the Chief Game Warden, who is also the Conservator of Forests.

Prior to 1963 , all confiscated orang utans were exported to foreign zoos as it was impossible to keep them in Sabah over a period of years. Thirteen went to Europe and seven to Australia. Exports ceased with the formation of the game branch in I964. With a view to returning the animals to the wild, a small-scale experiment was started in the I0,000-acre Sepilok Forest Reserve, near Sandakan, where there is a small population of feral orangs. Mrs Barbara Harrison, who had established a similar project in Sarawak, helped with advice.

The reserve is well stocked with the larger timber trees, and jungle fruit trees liked by orangs are quite well distributed-durian (Durio), terap (Artocarpus), rambutan and meritam (Nephelium), mangosteen (Garcinia), mata kuching (Euphoria).

The aims of the project, which is financed by the State, are to rehabilitate orang utans into the wild by gradually giving them more freedom in their natural surroundings, and to restore their survival instincts and encourage their self-reliance in the forest, so that they may return to the wild or form a semi-wild breeding colony to enhance Sabah's depleted wild stocks. As soon as the animals can survive on 
their own they will be released in batches in forests remote from both habitation and timber operations. The task is a difficult one; until recently very little was known about the ecology and ethology of feral orang utans, and moreover the behaviour of the animals in the experiment must be affected by the presence of, and contact with the staff in the establishment. Perhaps out of pure boredom animals which have been confined develop traits and habits that are unknown in the wild. We hope that, if the orangs are given their natural habitat and encouraged to climb, make nests and move freely in the forest, their instincts for survival will be aroused.

There are now 22 orangs at Sepilok and their estimated ages vary from about 3 to 13 years. Most arrived in poor condition-underweight (mainly the result of improper feeding) and sickly. Some had lived luxuriously in captivity and had been treated more or less like human beings, which obviously is not countenanced in Sepilok. Once domesticated, an animal cannot simply be liberated in the forest, and expected to live in the wild as if it had been there all its life. Most of the Sepilok animals had been in captivity, which changes them both psychologically and physiologically. They become subdued, increasingly dependent on their keepers, and acquire new habits and feeding patterns, making rehabilitation extremely difficult. One male, Henry, resorted to autostimulation whenever he saw a partly dressed human, having been trained to do so for the amusement of labourers at a timber camp. Another male, Moses, having been confined since infancy in an iron cage $5 \frac{1}{2} \mathrm{ft} \times 4 \frac{1}{2} \mathrm{ft} \times 3 \mathrm{ft}$, with bars at 2 in. intervals on all sides, was flat footed; his fingers could not be flexed due to atrophy of the muscles. Not wanting to walk, he squatted and pushed himself along the ground with the aid of his hands.

\section{The Daily Routine}

On arrival at Sepilok after a period of quarantine at the Veterinary Station, each orang is put with others of the same age group, and its reactions observed; it is fed and exercised under supervision. When once used to the company of other orangs and the attendants, it is allowed to exercise on its own, climb trees and feed with the others, and gradually it adjusts itself. The cage doors are open 24 hours a day and the animals have complete freedom. Every morning, about 7 a.m., all the animals available are examined for symptoms of illness, then fed and allowed to roam. At Io a.m. milk with Complan (made by Glaxo Ltd) is brought, and on seeing it, or being called, animals near the cages will come down from the trees. The third meal is at 5 p.m., after which they go to sleep in the trees or in the cages; some of the more independent animals sleep in nests. In 1966, to induce the larger animals to become more self-reliant, we constructed a cage some distance from the centre and took five animals, Joan, Cynthia, Cocoa, Sam and Moses, out to it. Joan was allowed free, the other four were confined at first; but when liberated two weeks later they continued to live near the cage and returned to it at dusk. As it was the fruit season, they fed in the vicinity of the cage; as long as fruit was abundant 
we reduced the milk and other food we had been giving them and occasionally cut it off completely. They did not seem to mind this, and were obviously feeding about an eighth of a mile away from the cage. After a time Joan disappeared, but returned within a week. Moses gradually increased his range and went off into the forest. Two years later when a search was made for orangs in Sepilok, rangers came across an animal which responded to the name Moses and to no other name, and was undisturbed by the immediate presence of observers; a feral female with an infant, on the other hand, was aggressive when observed. The different responses to humans suggested to the observers that the first animal was Moses, and one experienced ranger is certain that it was; I myself am sceptical.

At the end of the fruit season we again supplied the orangs with food, whereupon, although they roamed the vicinity of the cage, they made no attempt to feed in the forest. So we constructed tables at some distance from the cage and put the food on these twice daily. The orangs would then go no farther than the tables and would there await the arrival of food. The amount they ate showed that they were not feeding in the forest, and it looked as if they would become entirely dependent on the food tables. So we gradually reduced the amount of food put out on the tables and once the fruit season came round again destroyed the tables and stopped the food altogether. The animals then loitered near where the tables had been, but when no food appeared they began to wander away in search of it. Hunger was the best sauce. As there was abundant food available they began to increase their range and feed independently; and when the fruit supply waned they wandered further into the forest and ate whatever they could find. As they were now fending for themselves no food was supplied. Sometimes, keeping to the forest canopy, they would follow a ranger back to headquarters, where they were fed and then taken back to the forest, and this would be repeated. As it was impossible to prevent these visits they were tolerated, and animals now come and go as they wish. If they remain too long at the headquarters or are disinclined to go back they are returned to the forest.

One female, Mary Rose, came to Sepilok after being injured and captured during felling operations in 1968 when she was about $2 / 3$ years old. The fall having broken her left femur and humerus, these were pinned by a team of veterinarians at Kota Kinabalu, and she was returned to Sandakan where she recovered the use of her limbs, but at no stage was any attempt made to tame her. On arrival at Sepilok she immediately climbed a tree. For some time she exercised in the trees close to a cage, gradually extending her range, until in May, 1969, she disappeared. In June she was found, in good condition, exercising on a tree not far from the centre.

Several confiscated babies whose estimated ages ranged from $\mathrm{I} \frac{1}{2}$ to 3 years averaged only 3 to 4 pounds in weight when they arrived, and it was assumed that they were grossly underdeveloped. But the weight and growth rate of these animals compare very favourably with that of Joanne, born May 25, 1967, who was sired by a feral orang, and who 
was looked after from infancy by the mother. Moreover, well nourished animals brought up elsewhere rapidly lost weight in Sepilok, then became more active and gradually increased their weight.

Most captive orangs become worm-infested, mainly as a result of improper care, and have hook worm (Ankylostome) and roundworm (Ascaris) infections. In captivity and in the semi-wild state they are also susceptible to malaria, bronchial and dermatological infections, amoebic dysentery, hepatitis, bacillus coli infections, liver abscesses and melioidosis. In I965 Nellie died of melioidosis and in 1968 another case proved fatal. All the available apes were examined, but tests proved negative. The organism was later detected in some soil and water at Sepilok.

Orang utans use the bark, leaves and branches of trees for food and for building nests, and observations in Sepilok indicate a considerable rate of tree destruction within a short time.

The behaviour of the captive orang tends to be governed by its environment and its keeper's attitude towards it. Joan refused to sleep till she was securely chained at night, and a case of auto-erotism has already been mentioned. At Sepilok some apees often watch labourers cutting firewood and carrying it back to their camp, and when the men have gone imitate their actions. Some apes will use tools. Some staff members at Sepilok, perhaps unwittingly, have a tendency to pay more attention to a particular animal. A strong bond is then built up and the animal often regards its keeper with affection. Once, in the absence of the veterinarian, I looked after Paul for some time; he would fly into fits of rage if I administered to the needs of other sick apes. Another time a newly arrived adult male deliberately and without provocation savaged a ranger. Its behaviour may have been governed by either environmental change, emotional instability, strong attachment to its former keepers or resentment towards strangers who had usurped the keepers' role. Another ape, who had acquired a taste for cigarettes, beer and whisky, craved for tobacco. It would get irritable, grapple with the staff, and snatch their cigarettes.

Auto-erotism is common and starts at an early age. The males often have frequent erections of the penis, sometimes induced. Juvenile males also touch and pull the sex organs of other animals and attempt copulation. They are not repulsed by females, but successful intromission has not been observed.

\section{Territorial Limits and Behaviour}

Little is known about the territorial limits and behaviour of wild orangs. It would be interesting to learn whether territory is defended by actual fighting or by aggressive displays. In 1968, two game rangers observed Joan and her infant in Sepilok constructing a nest on a tree together with a feral orang also with a baby. After constructing the nest, both females occupied it and hugged each other. While this was going on the feral baby was on its own, but close to its mother. When the wild orang spied the observers, she collected her baby, climbed higher up the tree and threw branches in their direction. Joan, however, came 
towards them and was content to stay with them. As this was the only observation of its kind no conclusions are drawn, but this was not the first time Joan had fraternised with a wild orang.

Some time this year it is proposed to release four of the orangs, Joan, Joanne, Cynthia, and Cocoa, who should now be able to survive on their own. This will be done in a block of forest several hundred square miles in extent and remote from timber operations, in the head waters of the Segama river. The area may be constituted a game sanctuary for this and other purposes.

\section{Pledges for the Monkey-Eating Eagle}

President Marcos of the Philippines in August issued an order giving complete protection to the monkey-eating eagle. General Lindbergh, a WWF Trustee, recently attended a meeting of Philippine conservation officials and representatives of logging firms on Mindanao at which the latter pledged their support for the efforts to save the eagle.

\section{Lynx in East Germany}

Several lynx have been seen on the Dueben Heath, a large forest area near Leipzig. They are the first to be seen in the territory of the present GDR (East Germany) for 200 years. The last one was shot in 1752 .

\section{Correction}

In the list of FPS overseas representatives published in the September ORYX, the names of two South African members were confused. These should have read Dr R. Bigalke and Professor R. C. Bigalke.

\section{Help to preserve wild animals by supporting}

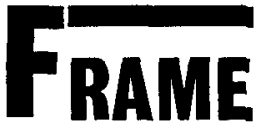

\section{FUND FOR THE \\ RePlacement of ANimals \\ IN MEDICAL EXPERIMENTS}

Large numbers of monkeys are imported and killed for their kidney tissues which are used in vaccine manufacture even though many contaminants have been found in such tissues.

FRAME is urging the use of human diploid cells instead which are free from contaminants, thus making vaccines safer for humans and saving the slaughter of thousands of primates.

Send for our pamphlet "Is the laboratory animal obsolete?" and read of the many possibilites for replacing animals in research: The Hon. Sec. FRAME, 35 Wool Road, London, S.W.20.

We need your support. Please give generously. 